\title{
Stability Effect and Biological Evaluation of Whey Protein as Antioxidant Enhancer on Rats
}

\author{
Mona A, Hassan ${ }^{1}$, Omar A.H. Ahmed-Farid ${ }^{2}$ \\ ${ }^{1}$ Food evaluation and food Science Department, National organization for Drug Control and Research. \\ ${ }^{2}$ Researcher, National Organization for Drug Control and Research (NODCAR), Giza 12553, Egypt.
}

\begin{abstract}
In order to evaluate the antioxidant effect of whey protein (wy) as a food supplement, in addition it is antidotal effect against the toxicity induced by environmental pollution. In vitro and In vivo study was carried out. The stability of flaxseed oil . Whey protein emulation was evaluated by Rancimat test. The emulation improved the stability than oil separately for storage period. Biologically, to investigate the prophylactic effect of whey protein against environmental, pollution by lead acetate. Forty eight male albino rats were namely divided into six groups. The tested groups received respectively, group (1) control (basal diet), group (2) whey proteins plus oil, group (3) lead, group (4) lead plus whey proteins, group (5) lead plus GSH and group (6) lead plus whey proteins plus oil. For the manipulated groups continued their treatments for four weeks. The manipulation rats with lead acetate caused significantly elevated levels of liver functions, lipid profiles, oxidative stress biomarkers factors of cell energy respectively in comparison with the control group and upon the emulsion of whey proteins and oil in addition whey proteins plus oil plus lead respectively. The histopathological examination showed an improvement of the obtained results revealed that liver tissues from whey protein and emulsion of whey proteins oil groups and gives the histology of liver a normal appearance.
\end{abstract}

Keywords: Whey protein, flaxseed oil, lead acetate, GSH, oxidative stress

\section{Introduction}

Oxidation metabolism is essential for the survival of cells but it generates free radicals and other reactive oxygen species (ROS) as a side effect, which can induce oxidative damage. Enhancement of the body's antioxidant defense mechanism through dietary supplementation such as dietary product fraction would seem to be a practical approach to reduce the level of oxidative stress. Dairy products and their fractions have been found to be ant oxidative, e.i whey proteins, casein, and lacto ferrin (Steijins and Van 2000 and Tong et al, 2000). Whey proteins, byproducts recognized as valuable food ingredient with functional properties is going acceptable as functional food ingredients, Previous studies have shown that there are bioactive peptides derived from whey proteins can exhibit a number of properties and enable them to exhibit ant oxidative activity. (Meisel and Schlimme 1996; Clare et al., 2000; Pihlantoleppala, 2001). Accordingly, there are concerns about the potential health effects of synthetic antioxidants and there for, the need for natural antioxidants has recently increased against oxidative effect (Park $\boldsymbol{e t}$ al., 2001) for this reason, there is growing intention of research focused on the development of natural antioxidants derived from food ingredients that could retard lipid oxidation.

Evidence from human studies and animal models have suggested that the acute liver toxicity induced by the environmental pollution plays an important role such as lead acetate in the pathogenesis of heart failure, diabetes and metabolic syndrome (Schwimmer et al., 2003; Saeed and Alwaleedi, 2015). Lead is a widespread natural element in the environment, it is considered as one of the main persistent and common environmental pollutions. Lead is used in production of various manufactured products such as paints and cosmetics. Due to its toxic cumulative action in the environment, lead can affect all biological systems from different sources including air, water and food.

Flaxseed oil considered beneficial additions to whey proteins as mentioned before and healthy diet and combining them can compound their health benefits. flaxseed oil contain alpha- linolenic acid, a precursor to the essential omega-3 fatty acid which converts into DHA and EPA- more active in the protection affected by food is probably mediated through multiple beneficial nutrients contained in these foods, including mono- vitamin, minerals, photochemical and plant protein .These diets may include un saturated fats from natural vegetable oils (Lavie et al., 2009).

The present study aimed to investigate the antioxidant and emulative effects of whey protein against lead acetate induce liver toxicity compared with reduced glutathione as a reference drug. 
Materials

\section{Materials and Methods}

Whey protein was obtained from Faculty of Agriculture. Cairo University. Food Sci. Dep of dairy milk, flaxseed oil obtained from National Center for Research. Unit of oil extraction, GSH obtained from Sigma Aldrich and lead acetate obtained from Loba Chemie, India.

Chemicals: All the used chemicals were analytical grade.

Animals:

Adult male albino rats weighting about $150 \pm 15 \mathrm{~g}$ were used in these experiment animals were kept under normal laboratory conditions in the animal house of National organization of drug control and research for one week before the start of the experiment rats were allowed to feed and water on uniformity diet.

Experimental design:

After an acclimatization period of one week, six equal group of forty eight adult male albino rats ( 8 rats each) Group $1 \mathrm{kept}$ as control feeding on basal diet, group 2 received orally whey proteins and flaxseed oil, group 3 treated with lead acetate, group 4 received a combination lead and whey proteins, group 5 received a combination lead and GSH, also group 6 treated with mixture of lead, whey proteins and flaxseed oil

Collection of blood samples:

Blood samples were withdrawn from the retro-orbital vein of each animal, under light anesthesia by diethyl ether, according to the method described by Cocchetto et al 1983. Blood was allowed to coagulate and then centrifuged at $3000 \mathrm{rpm}$ for $15 \mathrm{~min}$. The obtained serum was used to estimate the activities of liver function enzymes, total protein, total lipids, and lipid peroxidation.

Preparation of liver samples:

Immediately after blood sampling, animals were sacrificed by cervical dislocation and the liver tissues were rapidly removed, washed in ice-cooled saline, plotted dray and weighed. A weighed part of each liver was homogenized, using a homogenizer (Medical instruments, MPW-120, Poland), with ice-cooled saline $(0.9 \% \mathrm{NaCl})$ to prepare $20 \% \mathrm{w} / \mathrm{v}$ homogenate. The homogenate was then centrifuged at $4000 \mathrm{rpm}$ for $5 \mathrm{~min}$. The aliquot was used for the assessment of malondialdehyde (MDA), reduced glutathione (GSH), oxidized glutathione (GSSG), nitric oxide (NO), 8-hydroxy-2'-deoxyguanosine (8OHdG), ATP, ADP and AMP.

Measurements of total protein, albumin, and globulin using commercially available kits. The results were expressed in $\mathrm{g} / \mathrm{L}$ according to Bradford, (1976).

\subsection{Measurement of serum liver function enzymes:}

Hepatic dysfunction was assessed by measuring the elevation in serum levels of ALT, AST using commercially available kits. The results were expressed in u/l. (Reitman, and Frankels, 1957)

2.9. Measurements of total lipids $(\mathrm{g} / \mathrm{dl})$, cholesterol $(\mathrm{mg} / \mathrm{dl})$, HDL, Triglycerides $(\mathrm{g} / \mathrm{dl})$, using colorimetric method according to Zollner, and Kirsch, (1962); Stein, (1986); wahlefeld, (1974) and LDL =TC- (TG/5)HDL.

\subsection{Measurements of lipid peroxidation and antioxidants status:}

Lipid peroxidation, as an indicator of oxidative stress, was estimated by measuring malondialdehyde (MDA) (nmol/g liver)was determined by HPLC according to Karatepe, (2004); Glutathione reduced(GSH) and oxidized(GSSG)(mg/l) was determined by HPLC according to Jayatilleke and Shaw, (1993); nitric oxide (NO) (nmol/g tissue) content was determined by HPLC according to Papadoyannis, et al., (1999) and 8hydroxydeoxyguanosine $(8 \mathrm{OHdG}) \mathrm{nmol} / \mathrm{g}$ tissue was determined by HPLC according to Lodovici, (2000).

\subsection{Determination of adenosine tri-phosphate content (ATP, ADP and AMP) in liver tissues by HPLC:}

Rapid high performance liquid chromatography method was developed for determination of adenine nucleotides in different tissues, and it currently investigated the relation between regional blood flow and tissue contents of compounds involved in energy metabolism under physiological and pathological conditions. The detection of ATP by HPLC was done according to the method of Teerlink et al., 1993.

Statistical analysis:

Statistical analysis of the obtained data was performed using the general linear model (GLM) produced by Statistical Analysis Systems Institute (SAS, 2004). Significant differences among means were evaluated using Duncan's Multiple Range Test. The following linear model was applied:

$\mathrm{Yij}=\mu+\alpha \mathrm{i}+\xi_{\mathrm{ij}}$

Yij= Observation measured

$\mu=$ Overall mean

$\alpha \mathrm{i}=$ Effect of treatment .

$\xi \mathrm{Ij}=$ Experimental error assumed to be randomly distributed $(\sigma 2=0)$. 
Histopathological studies: Light microscopic examination of the liver of control rats revealed normal hepatic parenchyma with preserved and well organization lobular pattern with no evidence of fibrosis or inflammatory reaction Fig 6a, liver of rat from group (b)was treated with whey protein and flaxseed oil showing the normal histological structure of liver ( $\mathrm{H} \alpha$ Ex 400), liver of rat from group (c) showing congested dilated portal vein (pv), hyalinized wall ( double arrow)edema(arrow head), mild inflammation (arrow) and proliferated bile ducts(bd), liver of rat from group(d) showing mild to moderate pathological alteration were detected, where most of central veins display.

\section{Results}

Stability of flaxseed oil incorporated with whey proteins:

The oxidative stability, or storage life until development of rancidity, is an important factor in processing of oils. Therefore the aim of this study is to investigate the effect of whey proteins as antioxidant agent against the rancidity of flaxseed oil.

In order to achieve this purpose, reanimate method has been carried out for the measurement the activity of whey proteins blended with flaxseed oil against rancidity.

Table (1) oxidative stability of flaxseed oil with whey proteins by rancimate at $100^{\circ} \mathrm{c}$.

\begin{tabular}{|l|l|}
\hline Substances & Induction period / h \\
\cline { 2 - 2 } & Flaxseed oil \\
\hline Flaxseed oil & 3.13 \\
Whey protein + flaxseed oil & 4.05 \\
\hline
\end{tabular}

It can be noticed from table (1) that the combination of whey proteins with flaxseed oil caused an increase of stability of stability period up to 4 hours in comparison with the control (oil) 3.13 hours. The obtained data are agreement with that obtained by Hogan, Hsieh et al. (2015) who mentioned that obtained the role of milk protein fraction as antioxidant against lipid peroxidation. This finding indicate that the role of milk proteins fractions namely whey proteins against the rancidity of fatty foods.

Prophylactic effect of flaxseed oil blended with whey proteins on liver functions. In the present study thirty six male albino rats were subjected to feeding experiment for four successive weeks.

\section{Effect of whey proteins blended with flaxseed oil on total protein}

Table (2), Fig(1) shows the biological effect of whey proteins blended with flaxseed oil on total protein in comparison with negative control (Feeding on basal diet) and the manipulated groups with Lead, Lead plus why protein, Lead plus GSH and Lead plus whey protein and flaxseed oil respectively.

The obtained data revealed that significantly lower values of total proteins in the groups upon Lead in comparison with the manipulated groups with Lead, whey protein+ flaxseed oil. Also, significant differences exist in the groups treated with Lead + whey protein in comparison with tested group with Lead .It can be seen that whey $\mu$ hand an increases in total protein value of rats treated with Lead + GSH in comparison with the group 3 manipulated with Lead. It can be seen from afore mentioned data the blended of oil+ whey protein was more effective as antioxidant against the toxicity of Lead.

Concerning Albumin level in the rats that fed the whey protein + GSH even similar to control one compared with group feeding on Lead.

Regardless, globulin similar trend of results were observed .Prophylactic effect of whey proteins incorporated with flaxseed oil on Alt and Ast against Lead induced liver toxicity in male rats for four weeks.

Table 2: Protective effect of whey protein and flex seed oil on TP, Alb, Glob and A/G against lead induced liver toxicity in male rats for 4 weeks.

\begin{tabular}{|c|c|c|c|c|}
\hline \multirow[t]{2}{*}{ Groups } & \multicolumn{4}{|l|}{ Parameters } \\
\hline & $\begin{array}{l}\text { TP } \\
\text { g/dl }\end{array}$ & $\begin{array}{l}\text { Alb } \\
\text { g/dl }\end{array}$ & $\begin{array}{l}\text { Glob } \\
\text { g/dl }\end{array}$ & $\mathbf{A} / \mathbf{G}$ \\
\hline control & $6.68 \pm 0.25$ & $4.22 \pm 0.03$ & $2.50 \pm 0.08$ & $1.69 \pm 0.05$ \\
\hline WP+oil & $6.61 \pm 0.11$ & $4.29 \pm 0.04$ & $2.32 \pm 0.15$ & $1.88 \pm 0.13$ \\
\hline Lead & $5.18 \pm 0.17 \mathrm{a}$ & $3.66 \pm 0.06 \mathrm{a}$ & $1.52 \pm 0.16 \mathrm{a}$ & $2.52 \pm 0.24 \mathrm{a}$ \\
\hline Lead+WP & $5.72 \pm 0.08 \mathrm{ab}$ & $4.29 \pm 0.06 \mathrm{~b}$ & $1.43 \pm 0.12 \mathrm{a}$ & $3.12 \pm 0.32 \mathrm{ab}$ \\
\hline Lead+GSH & $5.85 \pm 0.05 \mathrm{ab}$ & $4.27 \pm 0.04 \mathrm{~b}$ & $1.57 \pm 0.08 \mathrm{a}$ & $2.76 \pm 0.20 \mathrm{a}$ \\
\hline Lead+WP+oil & $6.49 \pm 0.10 \mathrm{ab}$ & $4.25 \pm 0.04 \mathrm{~b}$ & $2.44 \pm 0.12 b$ & $1.76 \pm 0.09 \mathrm{~b}$ \\
\hline
\end{tabular}

- Data are expressed as Mean \pm S.E. for 6-rats/group

- a significant difference from control group at the same column with one way ANOVA at $\mathrm{P}<0.05$.

- $\quad \mathrm{b}$ significant difference from lead group at the same column with one way ANOVA at $\mathrm{P}<0.05$. 


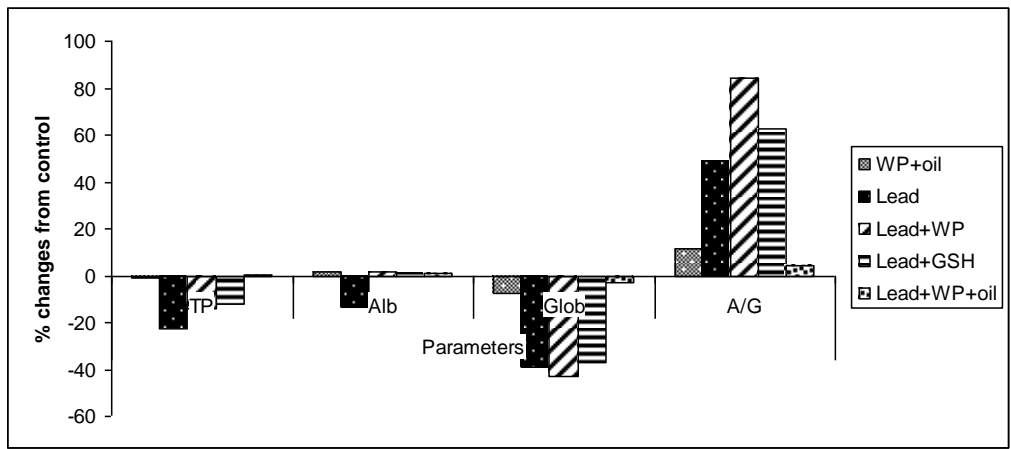

Fig 1: \% changes from control of TP, Alb, Glob and A/G protected by whey protein and flex seed oil against lead induced liver toxicity in male rats for 4 weeks.

\section{Effect of whey proteins and flaxseed oil on liver function enzymes}

Table (3) and Fig (2) show the impact of whey protein, flaxseed oil mixture on the hepato toxicity induced by Lead acetate. As for trans amines (ALT and AST), the ingestion of Lead acetate caused an increase in ALT and AST values from 32.162 and $58.211 \mu / \mathrm{L}$ to 60.276 and $93.538 \mu / \mathrm{L}$ respectively. Ingestion of whey protein + flaxseed oil and whey protein +oil+ Lead caused significant decrease in both parameters was found to be $41.724,76.511,33.954$ and $63.013 \mu / \mathrm{L}$ respectively in comparison with group feeding on Lead acetate. With regard to the aforementioned effect, feeding on Lead + GSH markedly reduction in Alt and Ast values was similar to that obtained by whey protein + oil.Prophylactic effect of whey proteins and flaxseed oil on lipid profile.

Table 3: Protective effect of whey protein and flex seed oil on ALT and AST against lead induced liver toxicity in male rats for 4 weeks.

\begin{tabular}{|l|l|l|}
\hline \multirow{2}{*}{ Groups } & Parameters & AST U/L \\
\cline { 2 - 3 } & ALT U/L & $58.211 \pm 1.934$ \\
\hline control & $32.162 \pm 0.657$ & $59.044 \pm 1.187$ \\
\hline WP+oil & $31.513 \pm 0.554$ & $93.538 \pm 0.645 \mathrm{a}$ \\
\hline Lead & $60.267 \pm 1.43 \mathrm{a}$ & $76.511 \pm 1.813 \mathrm{ab}$ \\
\hline Lead+WP & $41.724 \pm 0.682 \mathrm{ab}$ & $66.087 \pm 1.584 \mathrm{ab}$ \\
\hline Lead+GSH & $35.043 \pm 0.61 \mathrm{~b}$ & $63.013 \pm 1.606 \mathrm{~b}$ \\
\hline Lead+WP+oil & $33.954 \pm 0.503 \mathrm{~b}$ & \\
\hline
\end{tabular}

- Data are expressed as Mean \pm S.E. for 6-rats/group

- a significant difference from control group at the same column with one way ANOVA at $\mathrm{P}<0.05$.

- $\quad b$ significant difference from lead group at the same column with one way ANOVA at $\mathrm{P}<0.05$.

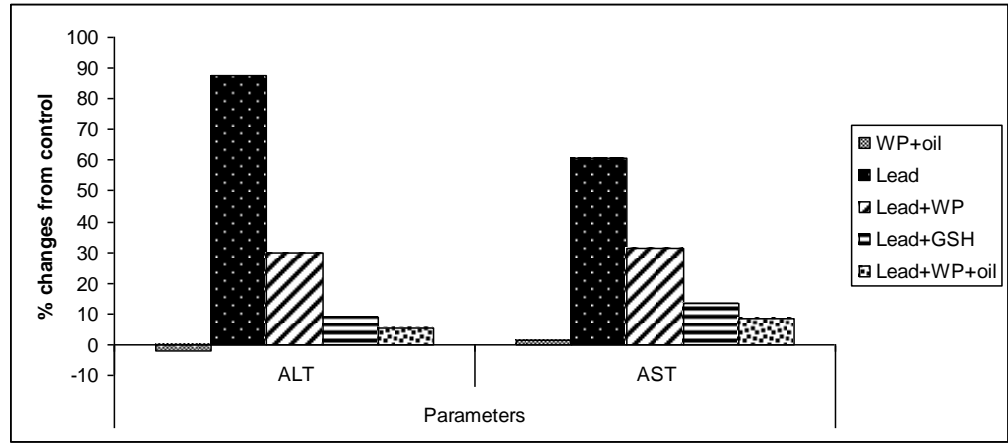

Fig 2: \% changes from control of ALT and AST protected by whey protein and flex seed oil against lead induced liver toxicity in male rats for 4 weeks.

\section{Effect of whey proteins and flaxseed oil on lipid profile}

Table (4) and Fig (3) show the effect of Lead ingestion, in comparison with whey protein mixture with oil and Lead on lipid profile. As mentioned before for liver function significant decrease in the lipid fractions namely T. cholesterol, T.glycerides, HDL and LDL were reduced in comparison with the group feeding on Lead. Concerning the mixture of Lead + GSH similar trend in results was noticed, Prophylactic effect of whey proteins and flaxseed oil on MDA, GSH, GSSG,No, and 8HDG against Lead induced liver toxicity in male rats for four weeks. Similar finding of results also were obtained about the antidotal effect of whey protein and GSH against the toxic effect of Lead acetate on MDA, GSH, GSSG,No and 8 HDG respectively. 
Table 4: Protective effect of whey protein and flex seed oil on TC, TG, HDL and LDL against lead induced liver toxicity in male rats for 4 weeks.

\begin{tabular}{|l|l|l|l|l|}
\hline \multirow{2}{*}{ Groups } & \multicolumn{5}{l|}{ Parameters } \\
\cline { 2 - 5 } & TC $\mathbf{~ m g / d l}$ & TG mg/dl & HDL mg/dl & LDL mg/dl \\
\hline control & $79.11 \pm 2.84$ & $100.3 \pm 1.95$ & $28.88 \pm 2.58$ & $30.16 \pm 3.64$ \\
\hline WP+oil & $80.74 \pm 2.35$ & $99.6 \pm 2.08$ & $25.89 \pm 2.54$ & $34.92 \pm 3.37$ \\
\hline Lead & $108.15 \pm 3.20 \mathrm{a}$ & $176.0 \pm 0.99 \mathrm{a}$ & $19.75 \pm 0.83 \mathrm{a}$ & $53.20 \pm 3.25 \mathrm{a}$ \\
\hline Lead+WP & $80.43 \pm 2.85 \mathrm{~b}$ & $100.8 \pm 2.23 \mathrm{~b}$ & $25.92 \pm 3.15 \mathrm{~b}$ & $34.34 \pm 4.57 \mathrm{ab}$ \\
\hline Lead+GSH & $77.30 \pm 1.71 \mathrm{~b}$ & $103.6 \pm 2.76 \mathrm{~b}$ & $30.67 \pm 2.62 \mathrm{~b}$ & $25.88 \pm 1.51 \mathrm{~b}$ \\
\hline Lead+WP+oil & $79.65 \pm 2.19 \mathrm{~b}$ & $102.9 \pm 2.52 \mathrm{~b}$ & $28.15 \pm 2.39 \mathrm{~b}$ & $31.30 \pm 3.83 \mathrm{~b}$ \\
\hline
\end{tabular}

- Data are expressed as Mean \pm S.E. for 6-rats/group

- a significant difference from control group at the same column with one way ANOVA at $\mathrm{P}<0.05$.

- $\quad \mathrm{b}$ significant difference from lead group at the same column with one way ANOVA at $\mathrm{P}<0.05$.

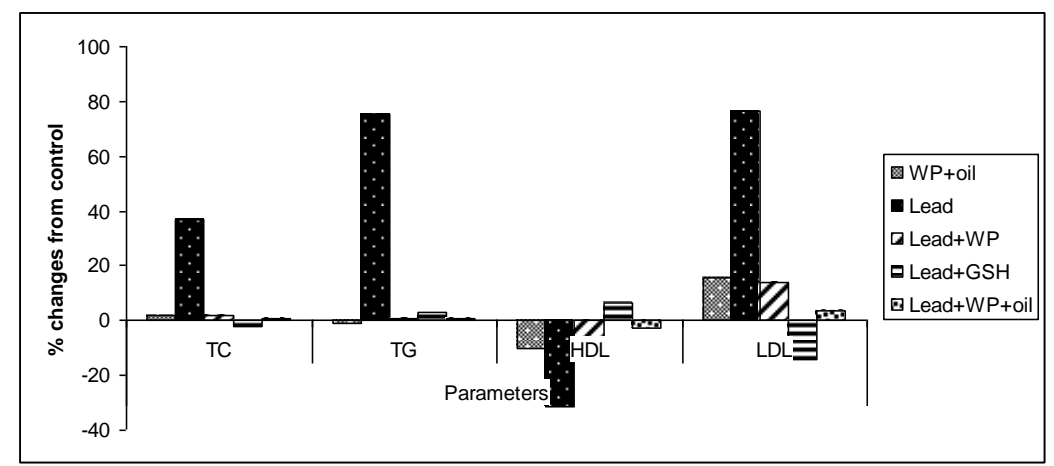

Fig 3: \% changes from control of TC, TG, HDL and LDL protected by whey protein and flex seed oil against lead induced liver toxicity in male rats for 4 weeks.

Effect of whey proteins and flaxseed oil on activity MDA, GSH, GSSG, NO, 8HDG activity

Table (5) \& Fig (4) show the extenuative effect of both whey proteins and GSH for Lead toxicity which may be attributed to the nature of whey protein and GSH to reduce Lead toxicity by binding with free radicals. Caused by the attack of Lead acetate to vital cells. The prophylactic effect of whey proteins and flaxseed oil on ATP, ADP and AMP against Lead induced Liver toxicity in male rats for four weeks.

Table 5: Protective effect of whey protein and flex seed oil on MDA, GSH, GSSG and 8HDG against lead induced liver toxicity in male rats for 4 weeks.

\begin{tabular}{|c|c|c|c|c|c|}
\hline \multirow[t]{2}{*}{ Groups } & \multicolumn{5}{|l|}{ Parameters } \\
\hline & $\begin{array}{l}\text { MDA } \\
\text { nmol/g tissue }\end{array}$ & $\begin{array}{l}\text { GSH } \\
\square \text { mol/g tissue }\end{array}$ & $\begin{array}{l}\text { GSSG } \\
\square \text { mol/g tissue }\end{array}$ & $\begin{array}{l}\text { NO } \\
\square \mathrm{mol} / \mathrm{g} \text { tissue }\end{array}$ & $\begin{array}{l}\text { 8HDG } \\
\mathrm{pg} / \mathrm{g} \text { tissue }\end{array}$ \\
\hline control & $11.28 \pm 0.80$ & $15.83 \pm 0.61$ & $0.493 \pm 0.02$ & $0.452 \pm 0.04$ & $211.70 \pm 2.96$ \\
\hline WP+oil & $10.63 \pm 0.81$ & $16.18 \pm 0.65$ & $0.422 \pm 0.03$ & $0.449 \pm 0.02$ & $221.68 \pm 4.06$ \\
\hline Lead & $26.58 \pm 1.43 \mathrm{a}$ & $9.25 \pm 0.34 \mathrm{a}$ & $0.528 \pm 0.01 \mathrm{a}$ & $0.520 \pm 0.03 \mathrm{a}$ & $287.87 \pm 9.91 \mathrm{a}$ \\
\hline Lead+WP & $13.73 \pm 0.51 \mathrm{a}$ & $13.39 \pm 0.69 \mathrm{ab}$ & $0.481 \pm 0.05 b$ & $0.472 \pm 0.04 b$ & $244.39 \pm 5.24 \mathrm{ab}$ \\
\hline Lead+GSH & $11.29 \pm 0.74 b$ & $15.61 \pm 1.02 \mathrm{~b}$ & $0.46 \pm 0.04 b$ & $0.481 \pm 0.03 b$ & $236.56 \pm 4.68 \mathrm{ab}$ \\
\hline Lead+WP+oil & $11.16 \pm 0.66 \mathrm{~b}$ & $16.05 \pm 0.75 b$ & $0.477 \pm 0.03 \mathrm{~b}$ & $0.409 \pm 0.04 \mathrm{~b}$ & $219.18 \pm 5.60 b$ \\
\hline
\end{tabular}

- Data are expressed as Mean \pm S.E. for 6-rats/group

- a significant difference from control group at the same column with one way ANOVA at $\mathrm{P}<0.05$.

- $\quad \mathrm{b}$ significant difference from lead group at the same column with one way ANOVA at $\mathrm{P}<0.05$.

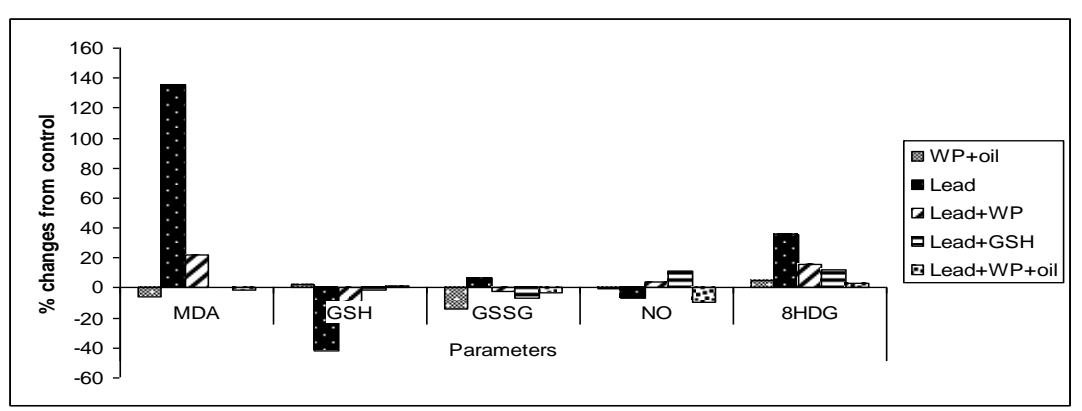

Fig4: \% changes from control of MDA, GSH, GSSG and 8HDGprotected by whey protein and flex seed oil against lead induced liver toxicity in male rats for 4 weeks. 


\section{Effect of whey protein and flaxseed oil on ATP, ADP, and AMP activity}

It is clear from the results recorded in Tab (6) and Fig (5) a significant increase in ATP value in the manipulated groups with WP\& GSH compared with the tested group with Lead acetate. It can be seen that a markedly increase in the group received WP\&P oil, which caused excess improvement in the activity of ATP value, compared with group feeding on lead. On the other hand a significant reduction in AMP values in all tested group comparison with the manipulated group with Lead acetate. Concerning ADP, it could be seen that the group manipulated with lead acetate cause an increase values comparing with negative and positive control.

Table 6: Protective effect of whey protein and flex seed oil on ATP, ADP and AMP against lead induced liver toxicity in male rats for 4 weeks.

\begin{tabular}{|l|l|l|l|}
\hline \multirow{2}{*}{ Groups } & Parameters & ADP $\square$ g/g tissue & AMP $\square$ g/g tissue \\
\cline { 2 - 4 } & ATP $\square$ g/g tissue & $18.15 \pm 0.51$ & $9.96 \pm 0.53$ \\
\hline control & $29.67 \pm 1.47$ & $17.09 \pm 0.59$ & $10.45 \pm 0.50$ \\
\hline WP+oil & $27.43 \pm 0.94$ & $22.25 \pm 0.83 \mathrm{a}$ & $17.98 \pm 0.60 \mathrm{a}$ \\
\hline Lead & $19.69 \pm 0.42 \mathrm{a}$ & $22.45 \pm 0.46 \mathrm{a}$ & $9.67 \pm 0.45 \mathrm{~b}$ \\
\hline Lead+WP & $29.78 \pm 1.08 \mathrm{~b}$ & $22.08 \pm 0.34 \mathrm{a}$ & $10.03 \pm 0.57 \mathrm{~b}$ \\
\hline Lead+GSH & $29.34 \pm 0.73 \mathrm{~b}$ & $22.66 \pm 0.70 \mathrm{a}$ & $10.52 \pm 0.46 \mathrm{~b}$ \\
\hline Lead+WP+oil & $30.36 \pm 1.38 \mathrm{~b}$ & & \\
\hline
\end{tabular}

- Data are expressed as Mean \pm S.E. for 6-rats/group

- a significant difference from control group at the same column with one way ANOVA at $\mathrm{P}<0.05$.

- b significant difference from lead group at the same column with one way ANOVA at $\mathrm{P}<0.05$.

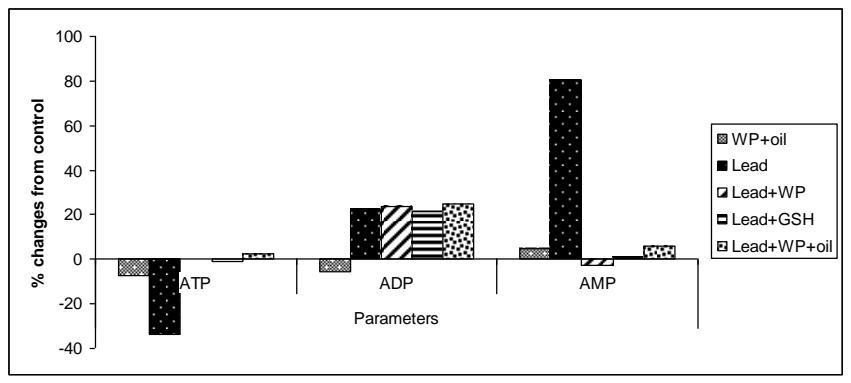

Fig 5: \% changes from control of ATP, ADP and AMP protected by whey protein and flex seed oil against lead induced liver toxicity in male rats for 4 weeks.

\section{Histopathological studies}

Light microscopic examination of the liver of control rats revealed normal hepathepatic parenchyma with preserved and well organized lobular pattern with no evidence of fibrosis or inflammatory reaction Fig 6a, liver of rat from group(b) was treated with whey protein and flaxseed oil showing the normal histological structure of liver (H\&Ex400), liver of rat from group(c) showing congested dilated portal vein (PV), hyalinized wall (double arrow), edema(arrow head), mild inflammation(arrow) and proliferated bile ducts (bd), liver of rat from group(d) showing mild to moderate pathological alteration were detected, where most of central veins display congestion, meanwhile portal areas showed restriction interlobular granuloma - like structure was detected, liver of from group(E) mild pathological alterations reflected pronounced degree of improvement, where focal areas of dilated congested sinusoids especially in the periphery of liver lobules, liver of rat from group $(\mathrm{F})$ showing approximately normal structure of liver.
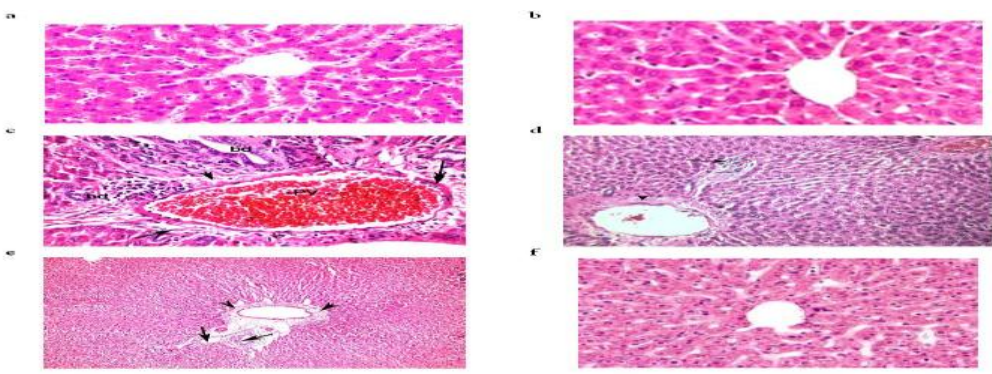

Fig 6: Haematoxylin and eosin-staind liver sections. A) Normal control. B) Group treated with whey protein and flaxseed oil .C) Group treated with lead acetate. D) Group treated with lead acetate and whey protein. E) Group treated with lead acetate and GSH. F) Group treated with lead, GSH and flaxseed oil. 


\section{Discussion}

According to the preceding view about the utilization of whey protein as natural antioxidant and antidotal biologically, it proved to be most effective antioxidant against the free radicals induced by lead acetate. Also, it could be seen that whey proteins may act as antidote for poising of pollutants. In addition, it proved to be most active by incorporation with vegetable oils among other synthetic antioxidants, namely GSH to reduce the rancidity and toxicity. However, the aforementioned results indicate clearly that the prophylactic effect may be attributed to the nature of whey proteins through binding or chelating with metals and the Presence of difference amino acids in different concentrations. In addition, the incorporation of whey proteins with flaxseed oil proved to be most effective compared with oil separately owing to the presence of active natural compounds in the oil. The ant oxidative activity of histidine - containing peptides has been reported Uchida and Kawakish, (1992). The presence of some amino acids has been considered as essential in order for the antioxidant activity. This activity has taken on major importance in the ant oxidative properties of histidine containing peptides Chen et al. (1998). Ibrahim, et al. (2012) who found that whey hydro lysates could be suitable as natural ingredients in enhancing antioxidant properties of functional foods and preventing oxidation reaction in food processing. Pins, and Keenan, (2006). who found that whey peptides caused a decrease in LDL cholesterol, and improve blood pressure, low-density lipoprotein cholesterol and high sensitivity c-reactive protein were significantly improved by treatment with hydrolyzed whey protein supplement rich in bioactive peptides. Beena and Prasad, (1997). who reported that there was marked lowering of LDL. Cholesterol in rats given either type of yogurt fortified with whey protein. Beena and Prasad, (1997). who reported that whey, dairy fraction can be used to produce dairy prodict with more beneficial effects on plasma lipid profile. On the other hand Hamad et al. (2011) proved the regulatory effect of whey proteins by improving or reducing the oxidative stress parameters With respect to histopatholgical finding rats received whey proteins and emulsion of whey proteins plus oil no obvious differences in the tissues and appeared to be somewhat similar to control. The obtained results concerning the prophylactic effects of whey proteins are agreement with that found by Eliwa $\boldsymbol{e t}$ al. (2014) who reported that the induction of hepatotoxicity by oral administration of whey proteins . Also, Abdel-Wahba, and Ibrahim, (2013) Mentioned that whey proteins useful as pharmaceutical agents that suppress hepatic fibrosis. Again, Germoush, (2014), reported that the combination with vit.c may be promising pharmaceutical tools in providing a natural antioxidant source against haptic toxicity. On the other hand, AbdelMoneim et al. (2011) suggested that possibility of flaxseed oil use fullness in limiting toxicant induced by environmental heavy materials. Finally, Oryan et al. (2010) mentioned that the supply of whey proteins diet decreased DMN- induced liver damage and, therefore, had beneficial effects on hepatic failure.

\section{Conclusion}

It can be extracted from the obtained data that, the oral administration of whey proteins as supplemental food plays a role in regulation against the oxidative stress in hepatotoxicity and natural antioxidant in fatty foods.

\section{References}

[1]. Abdel-Moneim, AE. Dkhil, MA. and Al-Quraishy, S. (2011). The potential role of flaxseed oil on lead acetateinduced kidney injure in adult male albino rats. African Journal of Biotechnology. 10(8), 14361451.

[2]. Abdel-Wahba, HM and Ibrahim, TAA. (2013). Protective effect of flaxseed oil and vitamin E on potassium Bromate-induced oxidative stress in male rats. Int. J. Curr. Microbiol. App. Sci. 2(9): 299-309.

[3]. Beena A, Prasad V. (1997). Effect of yogurt and bifidus yogurt fortified with skim milk powder, condensed whey and lactose-hydrolysed condensed whey on serum cholesterol and triacylglycerol levels in rats. J Dairy Res; 64(3):453-7.

[4]. Bradford MM. (1976). A rapid and sensitive method for the quantitation of microgram quantities of protein utilizing the principle of proteindye binding. Anal Biochem, 72: 248-254.

[5]. Chen, HM. Muramoto, K. Yamauchi, F. Fujimoto, K. and Nokihara, K. (1998). Antioxidative Properties of Histidine-Containing Peptides Designed from Peptide Fragments Found in the Digests of a Soybean Protein. J. Agric. Food Chem. 46 (1), pp 49-53.

[6]. Clare DASwaingood HE 2000 bioactive milk peptides:aprospectus J Dairy sci83: 1187-1195

[7]. Cocchetto, D.M. and Bjornsson, T.D. (1983). Methods for vascular access and collection of body fluids from the laboratory rat. J Pharm Sci, 72, 465-92.

[8]. Eliwa, HA . El-Denshary, ES, Nada, SA. Elyamany, MF. Omara, EA. Asaaf, N. (2014). Evaluation of the Therapeutic Effect Of Whey Proteins on The Hepatotoxicity Induced By Paracetamol and Alcohol Co administration in Rats. IJPRBS, 3(2): 295-314.

[9]. Germoush, MO. (2014). Protective effect of hesperidin against ammonium chloride-induced hyperammonemia in rats. Life Science Journal, 11(7). 
[10]. Hamad, EM , Taha. SH , Abou Dawood. AI , Sitohy. MZ and Abdel-Hamid M. (2011). Protective effect of whey proteins against nonalcoholic fatty liver in rats. Lipids in Health and Disease, 10:57.

[11]. Hsieh, CC. Hernández-Ledesma, B. Fernández-Tomé, S. Weinborn, V. Barile, D and María, J. (2015). Milk Proteins, Peptides, and Oligosaccharides: Effects against the 21st Century Disorders. BioMed Research International. 146840, 16.

[12]. Ibrahim, NM. Eweis, EA. El-Beltagi, HS. Abdel-Mobdy, YE. (2012). Effect of lead acetate toxicity on experimental male albino rat. Asian Pac J Trop Biomed; 2(1): 41-46.

[13]. Jayatilleke E and Shaw S1993A high performance liquid chromatographic assay for reduced and oxidized glutathione in biological samples AnalBiochem: 2142: 452-457

[14]. Karatepe M2004Simulatenous determination of ascorbic acid and free malondialdehyde in human serum by HPLC-UV Chromatographic Line 12: 362-365

[15]. Lavie CJ MilaniRV Mehra MR ventura Ho2009 Omega3 polyunsaturated fatty acids and cardiovascular diseases J Am collcardeil 54: 585-594

[16]. Lodovici M Casalini C Cariaggi R Michelucci L and Dolara P2000 Levels of 8-hydroxydeoxyguanosine as a marker of DNA damage in human leukocytes Free Radical Bio Med 28:13-17

[17]. Meisel H Schlimme E1996 Bioactive peptides derived from milk proteinsingredients for functional foods Kiel Milchwforsch 48: 343-457

[18]. Oryan, A. Eftekhari, MF. Ershad, M. Reza, MP and Tabatabaei, HR. (2010). Hepatoprotective effects of whey protein isolate against acute liver toxicity induced by dimethylnitrosamine in rat. Comp Clin Pathol. DOI 10.1007/s00580-010-0986-5.

[19]. Papadoyannis LN Samanidou VF and NitsosChC1999Simultaneous determination of nitrite and nitrate in drinking water and human serum by high performance anion-exchange chromatography and UV detection J Liq Chrom Rel Technol 2213: 2023 - 2041

[20]. Park PJ Zung WK Name KS Shahidi F Kim SK2001 purification and characterization of antioxidation peptides from lecithin- free egg yolk protein Jam oil chem Soc 78:651-656

[21]. Pihlantoleppala A2000Bioactive peptides derived from bovine whey proteins : opioid and ACEinhibitory peptides trends food Sci Tech 11:347-356

[22]. Pins, JJ. and Keenan, JM. (2006). Effects of whey peptides on cardiovascular disease risk factors. J. Clin Hypertens (Greenwich). 8(11):775-82.

[23]. Reitman S and FrankelS1957 Calorimetric determination of AST and ALT activity Am J Clin Path 28: 56-63

[24]. Saeed A Alwaleedi 2015Hemato- Biochemical changes induced by lead in toxication in male and female albino mice International Journal of Recent Scientific Research vol G issue Spp3999-4004

[25]. SAS. Statistical Analysis Systems Institute SAS/STAT user's guide: release 6.03. SAS institute Inc., Cary, NC. USA. (2004).

[26]. Schwimmer JB Deutslch R Rouch JB Behling C Newbury R Lavins2003 Insulin resistance and other clinco pathological correlateJBObseity143 $500-505$

[27]. Steijins ZM Van Hac2000 Occurrence structure biochemical properties and technological characteristics of lactoferrin Br J Nutr 84 :S11:S

[28]. Stein EA1986: Textbook of Clinical Chemistry Tietz editorWB Saunders Philadelphia N W USA pp879886

[29]. Teerlink T, Hennekes M, Bussemaker J, Groeneveld J. (1993). Simultaneous determination of creatine compounds and adenine nucleotides in myocardial tissue by high-performance liquid chromatography. Analytical biochemis-try; 214(1):278-83.

[30]. Tong LM Sasakis S Mc Clements DJ DeckerEA 2000 Mechanisms of the antioxidant activity of a high molecular weight fraction of wheyJ Agric Food Chem 48: 1473-1478

[31]. Uchida, K.; Kawakish, S. (1992). Sequence-dependent reactivity of histidine-containing peptides with copper(II)/ ascorbate. J. Agric. Biol. Chem. 40, 13-16.

[32]. Wahlefeld AW 1974Methods of Enzymatic Analysis 5th H U Bergmeyer Ed Academic Press New Yorkpp 1831-1835

[33]. Zollner N and Kirsch K1962Ueber die quantitative bestimnung von lipoiden mikromethod mittels der vielennaturlichellipoiden allenbekanntenplasmalipoiden gemeisamensulphophospho-vanillinreaction Zges exp Med: 135:545-561. 